\title{
Front Matter: Volume 6971
}

, "Front Matter: Volume 6971," Proc. SPIE 6971, Acquisition, Tracking, Pointing, and Laser Systems Technologies XXII, 697101 (1 April 2008); doi: 10.1117/12.798028

SPIE Event: SPIE Defense and Security Symposium, 2008, Orlando, Florida, SPIE. United States 


\section{PROCEEDINGS OF SPIE}

\section{Acquisition, Tracking, Pointing, and Laser Systems Technologies XXII}

Steven L. Chodos

William E. Thompson

Editors

18, 20 March 2008

Orlando, Florida, USA

Sponsored and Published by

SPIE

Volume 6971 
The papers included in this volume were part of the technical conference cited on the cover and title page. Papers were selected and subject to review by the editors and conference program committee. Some conference presentations may not be available for publication. The papers published in these proceedings reflect the work and thoughts of the authors and are published herein as submitted. The publisher is not responsible for the validity of the information or for any outcomes resulting from reliance thereon.

Please use the following format to cite material from this book:

Author(s), "Title of Paper," in Acquisition, Tracking, Pointing, and Laser Systems Technologies XXII, edited by Steven L. Chodos, William E. Thompson, Proceedings of SPIE Vol. 6971 (SPIE, Bellingham, WA, 2008) Article CID Number.

ISSN 0277-786X

ISBN 9780819471628

Published by

SPIE

P.O. Box 10, Bellingham, Washington 98227-0010 USA

Telephone +1 3606763290 (Pacific Time) · Fax +1 3606471445

SPIE.org

Copyright (c) 2008, Society of Photo-Optical Instrumentation Engineers

Copying of material in this book for internal or personal use, or for the internal or personal use of specific clients, beyond the fair use provisions granted by the U.S. Copyright Law is authorized by SPIE subject to payment of copying fees. The Transactional Reporting Service base fee for this volume is $\$ 18.00$ per article (or portion thereof), which should be paid directly to the Copyright Clearance Center (CCC), 222 Rosewood Drive, Danvers, MA 01923. Payment may also be made electronically through CCC Online at copyright.com. Other copying for republication, resale, advertising or promotion, or any form of systematic or multiple reproduction of any material in this book is prohibited except with permission in writing from the publisher. The CCC fee code is 0277-786X/08/\$18.00.

Printed in the United States of America.

Publication of record for individual papers is online in the SPIE Digital Library.

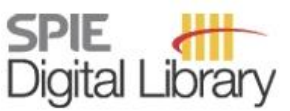

SPIEDigitalLibrary.org

Paper Numbering: Proceedings of SPIE follow an e-First publication model, with papers published first online and then in print and on CD-ROM. Papers are published as they are submitted and meet publication criteria. A unique, consistent, permanent citation identifier (CID) number is assigned to each article at the time of the first publication. Utilization of CIDs allows articles to be fully citable as soon they are published online, and connects the same identifier to all online, print, and electronic versions of the publication. SPIE uses a six-digit CID article numbering system in which:

- The first four digits correspond to the SPIE volume number.

- The last two digits indicate publication order within the volume using a Base 36 numbering system employing both numerals and letters. These two-number sets start with 00, 01, 02, 03, 04, 05, $06,07,08,09,0 \mathrm{~A}, 0 \mathrm{~B} \ldots \mathrm{OZ}$, followed by $10-1 \mathrm{Z}, 20-2 \mathrm{Z}$, etc.

The CID number appears on each page of the manuscript. The complete citation is used on the first page, and an abbreviated version on subsequent pages. Numbers in the index correspond to the last two digits of the six-digit CID number. 


\title{
Contents
}

\author{
$\checkmark$ Conference Committee \\ vii Introduction
}

\section{SESSION 1 SIGNAL/IMAGE PROCESSING FOR TRACKING}

697103 A hardware neural network for target tracking [6971-02]

W. C. Deck, G. Labonté, Royal Military College of Canada (Canada)

697105 A unified framework for capturing facial images in video surveillance systems using cooperative camera system [6971-04]

F. Chan, Y.-S. Moon, J. Chen, Y.-K. Ma, W.-H. Tsang, K.-K. Fu, The Chinese Univ. of Hong Kong (Hong Kong China)

697107 Multisensor 3D tracking for counter small unmanned air vehicles (CSUAV) [6971-06] J. R. Vasquez, K. M. Tarplee, Numerica Corp. (USA); E. E. Case, A. M. Zelnio, B. D. Rigling, Wright State Univ. (USA)

697108 A robust real-time object detection and tracking system [6971-07]

Z. Yue, P. L. Narasimha, P. Topiwala, FastVDO, Inc. (USA)

697109 Simulation of video sequences for an accurate evaluation of tracking algorithms on complex scenes [6971-09]

C. Dubreu, Cedip Infrared Systems and ENSTA (France); A. Manzanera, ENSTA (France);

E. Bohain, Cedip Infrared Systems (France)

\section{SESSION 2 HARDWARE IMPLEMENTATION}

6971 OB Application of network control systems for adaptive optics [6971-10]

R. J. Eager, Boeing, AFRL/RDS (USA)

6971 OC Control of a deformable mirror subject to structural disturbance [6971-11]

M. R. Allen, J. J. Kim, B. Agrawal, Naval Postgraduate School (USA)

$6971 \mathrm{OE} \quad$ A unique three-axis gimbal mechanism [6971-13]

J. M. Hilkert, Alpha-Theta Technologies (USA); M. Jonas, The Raytheon Co. (USA)

$6971 \mathrm{OF}$ Sin/cosine encoder interpolation methods: encoder to digital tracking converters for rate and position loop controllers [6971-14]

S. T. Jenkins, Texas Instruments (USA); J. M. Hilkert, Alpha Theta Technologies (USA)

6971 OG Analog, non-mechanical beam-steerer with 80 degree field of regard [6971-15]

S. R. Davis, G. Farca, S. D. Rommel, A. W. Martin, M. H. Anderson, Vescent Photonics, Inc. (USA) 
$6971 \mathrm{OH} \quad$ Deriving predictive turbulence data models [6971-16]

H. Jaenisch, Alabama A\&M Univ. (USA) and Licht Strahl Engineering, Inc. (USA);

J. Handley, Licht Strahl Engineering, Inc. (USA); M. Curley, M. Edwards, J.-C.Wang, Alabama A\&M Univ. (USA)

69710 Active and attentive LADAR scanning for automatic target recognition [6971-17]

M. T. Mamanakis, R. R. Fullmer, R. T. Pack, S. Budge, Utah State Univ. (USA)

POSTER SESSION

6971 OK Energy efficient collaborative target tracking by Gaussian Rao-Blackwellised particle filter in wireless sensor networks [6971-08]

Z. YU, J. Wei, H. Liu, Shanghai Institute of Microsystem and Information Technology (China)

Author Index 


\title{
Conference Committee
}

\author{
Symposium Chair
}

Larry B. Stotts, Defense Advanced Research Projects Agency (USA)

Symposium Cochair

Ray O. Johnson, Lockheed Martin Corporation (USA)

Symposium Track Chair

Ivan Kadar, Interlink Systems Sciences, Inc. (USA)

Conference Chairs

Steven L. Chodos, Boeing-SVS, Inc. (USA)

William E. Thompson, Air Force Research Laboratory (USA)

Conference Cochair

Ali T. Alouani, Tennessee Technological University (USA)

Program Committee

James E. Kimbrell, L-3 Brashear (USA)

Jim F. Riker, Air Force Research Laboratory (USA)

William D. Blair, Georgia Tech Research Institute (USA)

John E. Gray, Naval Surface Warfare Center (USA)

Gillian K. Groves, Raytheon Company (USA)

Christopher J. Musial, Boeing-SVS, Inc. (USA)

James M. Hilkert, Alpha-Theta Technologies (USA)

Glenn A. Tyler, The Optical Sciences Company (USA)

Juan R. Vasquez, Air Force Institute of Technology (USA)

Session Chairs

$1 \quad$ Signal/Image Processing for Tracking

Steven L. Chodos, Boeing-SVS, Inc. (USA)

2 Hardware Implementation

William E. Thompson, Air Force Research Laboratory (USA)

3 System Applications

Ali T. Alouani, Tennessee Technological University (USA) 
Downloaded From: https://www.spiedigitallibrary.org/conference-proceedings-of-spie on 26 Apr 2023

Terms of Use: https://www.spiedigitallibrary.org/terms-of-use 


\section{Introduction}

The SPIE Acquisition, Tracking, and Pointing and Laser System Technologies conference continues a 22-year tradition of providing a well-documented annual assessment of on-going, practical acquisition, tracking, and pointing technology. The conference has focused on both theory and practice and has spanned all aspects of design, analysis, simulation, development, and testing. As a result, the last twenty-plus years of proceedings from this conference provide a comprehensive history of the major technical developments within this field. This year also represents the third year of an expansion in the conference's scope, as the result of merging with the SPIE Laser Systems Technologies conference in 2006. This increased scope now includes other optics and beam control technologies, such as adaptive optics and line-of-sight stabilization, which are needed for many implementations of laser-based acquisition, tracking, and pointing systems in the field.

Locating, identifying, locking onto, and maintaining track on dynamic targets is absolutely essential for precision photonic and optical systems to be able to achieve their performance goals. Indeed, if the line-of-sight orientation of an optical sensor can not be maintained toward its target, or in some applications, if a laser can not provide continuous illumination of its target, then the whole purpose of the entire optical system is lost. As technical improvements are realized for optical sensors and laser sources, similar progress for acquisition, tracking, and optical control are necessary to fully exploit these technical advances in fieldable optical systems. Such progress requires advancements in active and passive imaging sensors, optics, gimbal-pedestal and mirror mechanisms, control systems, sensor stabilization, real-time imaging, signal processing, target tracking, and sensor fusion, as well as other related sensor and control tasks. Additionally, a frequent theme in the development of optical systems is the requirement to operate in an environment and/or on a platform that significantly stresses the state of the art for optical control, because of platform dynamics, difficult propagation conditions between the optical system and the intended target, complex target and target scene phenomenology, and constraints on the optical system's weight, volume, power consumption, platform interfaces, etc. Successfully meeting these requirements takes creativity and innovation, leading to new hardware designs, control architectures, processing algorithms, and other advances in the state of the art that can often be used to advantage in other optical system designs and applications.

The specific advancements included in the 2008 conference reported in these Proceedings include: target acquisition, recognition, and tracking algorithms, neural network processing for target tracking, control systems for adaptive optics and deformable mirrors, gimbal/pointing mechanism designs, electronic beam 
steering, propagation phenomenology, and new techniques for the simulation of optical tracking systems performance.

The two decade long-running success of this SPIE Conference is clearly dependent on many authors and their sponsoring organizations who freely share their work with others. We extend a sincere appreciation to each of these contributors, as well as our fellow conference organizers who actively encourage their colleagues and professional associates to be a part of this event. We also recognize and appreciate the excellent SPIE staff that makes organizing these conferences such a pleasant experience.

Watch for the call for papers for the 2009 conference, Acquisition, Tracking, Pointing, and Laser Systems Technologies XXIII. We expect to continue the present scope of the conference with only minor changes.

Steven L. Chodos William E. Thompson 